\title{
Areas of concern in mediation as a way of corporate disputes settlement
}

\author{
Tatiana Stanislavovna Korobeinikova ${ }^{1}$ \\ Far Eastern Institute of Management, Branch of RANEPA, Department of Public and Private Law, \\ Khabarovsk, Russia
}

\begin{abstract}
The purpose of the study involves systemic identification, generalization of the issues of legal regulation of the mediation procedure in corporate disputes settlement based on summarizing judicial practice, scientific research and the regulatory framework. The analysis of judicial practice, statistical data, scientific publications, as well as deduction and synthesis are the methodological basis of the research. The use of these methods made it possible to characterize the mechanism and advantages of using mediation in the settlement of corporate disputes; to identify problems in the application of the mediation procedure; to propose measures for improvement of the legal regulation of mediation, its application in corporate disputes in the Russian Federation. The research results obtained during the analysis of judicial practice and statutory instruments regulating the use of mediation in corporate disputes made it possible for the author to identify a number of problems and possible solutions to them, which are included in the author's proposals and can be used to improve Russian legislation in terms of corporate disputes settlement using mediation procedures. Moreover, it was substantiated by the author that mediation as a tool for a quick disputes settlement, the preservation of partnership relations after using the mediation procedure will be used more often in the event of a change in Russian legislation. The scientific novelty of the study lies in determining the possibilities of mediation in corporate disputes settlement within the framework of Russian legislation and identification of existing gaps in such regulation.

Keywords: corporate dispute, mediation as an out-of-court method of dispute settlement, settlement agreement, independent mediation, dispute resolution
\end{abstract}

\section{Introduction}

The use of mediation as an out-of-court way of settling relations has not gained popularity in Russia, while in foreign countries, resorting to the services of a mediator is in demand. Corporate disputes settlement is one of the pressing problems of domestic jurisprudence, which is associated with their negative impact on the economic potential of an enterprise and industries. The adoption of a special law on mediation in the Russian Federation undoubtedly played an important role in the formation of the institution of mediation in

\footnotetext{
${ }^{1}$ Corresponding author: korobeynikova-ts@ranepa.ru
} 
Russia. However, participants in corporate relations more often resort to judicial protection of their rights than to the mediation procedure. According to the author, this procedure is developing insufficiently fast in Russia due to the imperfection of the legislation governing the mediation procedure and its use in disputes settlement, including corporate ones. Thus, the relevance of the research topic is due to the need to analyze the solution of problematic issues related to the use of mediation in corporate disputes settlement. Mediation as a form of alternative conflict resolution is convenient for the parties to the conflict, since it entitles the parties to choose means and actions in search of a compromise option; contributes to the adoption of a joint decision corresponding to their interests. The special socio-legal nature of mediation (mediation has the features of a legal procedure; the search for a solution is carried out by the parties independently, according to the specifics of the conflict, based on a compromise) also contributes to the spread of mediation, moreover, 69\% of corporations use mediation as their main conflict settlement mechanism [1]. According to Shamlikashvili, "such quality as the informal, confidential process in which the parties participate on an equal footing, maintaining full control over both the decision-making process itself and its content is both the feature and the advantage of mediation" [2]. However, mediation has not become a popular instrument for settlement the disputes in the field of economic relations, which is due to both the peculiarities of the Russian legal consciousness, the weakness of civil society in our country and the lack of understanding by business entities of the advantages of mediation in corporate disputes settlement.

The purpose of the study is systemic identification and generalization of the issues of legal regulation of the mediation procedure in corporate disputes settlement on the basis of summarizing judicial practice, scientific research and the regulatory framework. Research objectives are the following: to characterize the mechanism and advantages of mediation in the corporate disputes settlement; to identify problems in the application of the mediation procedure; to propose the measures for improvement of the legal regulation of mediation, its application in corporate disputes in the Russian Federation.

Currently, scientists and practitioners are studying the issues related to mediation. In particular, Evdokimov, Nigmatullina, Altukhov, Baimakov, Elokhin considered certain aspects of the use of mediation in various areas of public life. Thus, the authors raise the issue of the theoretical understanding of mediation and the practice of its application in the modern world [3]. Some aspects of mediation were revealed by Nigmatullina in the study of the problems of reconciliation of the parties in the political sphere and the possibility of its application in public legal relations [4]. Svensson [5] explores the concept of conflict mediation.

Altukhov and Baimakov consider the prospects for the formation and development of the mediation procedure and formulate a number of recommendations for the popularization of mediation in Russia in their works [6, 7]. In turn, Elokhina studies the problems of mediation in Russia regarding the rights and obligations of the mediator himself, excluding the legal status of the parties to this process [8]. Sorokin, Virichenko reveal the advantages and disadvantages of mediation $[9,10]$. Some authors consider certain issues of using mediation procedures in resolving legal disputes [11-13].

Ostrovsky defines the directions and mechanisms for integration of mediation into the corporate governance system of Russian companies [14]. Frolovsky [15] analyzes the trends in the development of the corporate disputes institution. The essence of the conflict of interests and corporate dispute, as well as the approaches to their classification are studied by Malkina [16], Lipich and Tsukanova [17].

Meanwhile, in recent works, the authors consider the possibilities and features of mediation in corporate disputes settlement. For instance, Baibekova, Kalimullina note that 
mediation gives the best results in resolving disputes in corporate legal relations with minimal losses both in relation to the parties to the dispute and in relation to the corporation [18]. As a lack of mediation in resolving a conflict, Andreev and Laptev note that in this case, a "deal for a deal" is concluded, entailing the complication of the disputed legal relationship [19].

\section{Methods}

The analysis of judicial practice, statistical data, scientific publications, as well as the methods of deduction, synthesis, systemic and structural were used to achieve the goal and solve the corresponding problems.

\section{$3 \quad$ Results}

Analysis of judicial practice and regulatory legal acts governing the use of mediation in corporate disputes made it possible to identify a number of problems (Table 1).

Table 1. Some problems.

\begin{tabular}{|c|c|c|}
\hline $\begin{array}{l}\text { Ite } \\
\text { m }\end{array}$ & Problem & Possible solution \\
\hline 1 & $\begin{array}{l}\text { The settlement agreement } \\
\text { concerns only the subject of the } \\
\text { dispute and cannot consider the } \\
\text { entire set of relations between } \\
\text { the participants in the trial. It is } \\
\text { impossible to include } \\
\text { conciliatory conditions in the } \\
\text { settlement agreement that are } \\
\text { not enforceable in the course of } \\
\text { enforcement proceedings. }\end{array}$ & $\begin{array}{l}\text { It is necessary to include in the Code of Civil } \\
\text { Procedure of the Russian Federation and the } \\
\text { Arbitration Procedure Code of the Russian } \\
\text { Federation a norm stipulating the unacceptability of } \\
\text { rejection to approve a settlement agreement by the } \\
\text { court if there are conditions in it that cannot be } \\
\text { fulfilled through enforcement proceedings. In this } \\
\text { case, a writ of execution is not issued, and the court } \\
\text { explains to the parties the right to apply to the court } \\
\text { with a claim on the basis of the relevant provisions of } \\
\text { the settlement agreement. }\end{array}$ \\
\hline 2 & $\begin{array}{l}\text { The lack of a statutory } \\
\text { opportunity to use the services } \\
\text { of a foreign specialist as a } \\
\text { mediator. }\end{array}$ & $\begin{array}{l}\text { The possibility of foreign specialists in the field of } \\
\text { mediation procedures to provide services as } \\
\text { professional mediators in Russia, as well as to } \\
\text { determine the procedure for confirming their } \\
\text { qualifications and professionalism on the territory of } \\
\text { the Russian Federation should be stipulated in Law } \\
\text { No. 193-FZ. }\end{array}$ \\
\hline 3 & $\begin{array}{l}\text { The impossibility of securing } \\
\text { legislatively the circle of third } \\
\text { parties whose rights and } \\
\text { legitimate interests are affected } \\
\text { or may be affected as a result of } \\
\text { the mediation procedure. }\end{array}$ & $\begin{array}{l}\text { The duty of a mediator to identify and notify this } \\
\text { category of persons under out of court and pre-trial } \\
\text { protocol, on the basis of information provided by the } \\
\text { parties to the dispute in the course of its settlement } \\
\text { should be stipulated in Law No. 193-FZ. }\end{array}$ \\
\hline
\end{tabular}

Thus, in order to improve the legal regulation of the mediation procedure in corporate disputes, it is necessary to consider and implement the above proposals at the legislative level.

\section{Discussion}


According to Art. 1 of the Federal Law of 27.07.2010 No. 193-FZ "On an alternative procedure for disputes settlement with the participation of an intermediary (mediation procedure)" [20], mediation can be used in the field of corporate relations in various ways. For example, by contacting an external mediator. Commercial mediation is used to resolve disputes in the field of commercial legal relations, corporate governance and between parties that are not subordinate to each other.

Another option is to create in the corporation special departments, mediation services, whose functionality includes the settlement of disputes arising both within the company and with its counterparties (mediation in the organization). These services have a professional mediator who brings in the experts needed to make a decision. Mediation in this case is part of the organization's conflict management system.

In leading foreign companies, the corporate mediator is part of the top management [21]. He can act as a mediator in the conflict himself or select a mediator to resolve it. Solving conflicts between structural divisions of the corporation, the mediator helps to align the attitude in the team and thereby contributes to the efficiency of the company. In order to include mediation in the corporate governance of a company, it is necessary: to introduce into practice the assessment of each dispute for media viability; include a mediation clause in all contracts; train employees in mediation skills; declare the obligation to mediate disputes between departments.

The need for mediation in corporate disputes settlement is due to the parties' interest in continuing cooperation, the time rate of resolving the dispute, maintaining confidentiality, saving on legal support of the process in the event of a dispute being considered in court.

The definition of a corporate dispute is contained in Art. 225.1 of the Arbitration Procedure Code of the Russian Federation [22], according to which corporate disputes mean disputes related to the creation of a legal entity, its management or participation in a legal entity (Table 2).

Table 2. Judicial statistics of arbitration courts of the Russian Federation for corporate disputes settlement (statistics of the Judicial Department at the Supreme Court of the Russian Federation, 2015-2019) [23]

\begin{tabular}{|c|c|}
\hline Year & Cases considered (in thousands) \\
\hline 2015 & 13.7 \\
\hline 2016 & 15.7 \\
\hline 2017 & 18.4 \\
\hline 2018 & 20.3 \\
\hline 2019 & 20.8 \\
\hline
\end{tabular}

The analysis of judicial statistics shows the growth of corporate disputes over 5 years by almost 52\%, which indicates an increasing judicial burden and the need to work out measures to improve the procedure for corporate disputes settlement. The analysis of corporate disputes settlement through mediation made it possible to define the following areas of concern.

1. The execution of the settlement agreement in the order of enforcement proceedings is associated with its terms, which complicates the settlement of the dispute, taking into account the balance of interests of the parties. According to the Arbitration Procedure Code of the Russian Federation, in all cases, a writ of execution must be issued by an settlement agreement, as a result, many conditions of reconciliation that are beneficial to the parties and do not violate the rights of others are usually not included in the settlement agreement [24]. 
Meanwhile, there are other approaches in judicial practice. So in one of the cases, the Arbitration Court of the Rostov Region approved the mediation agreement as a settlement agreement. Despite the existence of conditions that go beyond the claims, the court did not find grounds for rejection of the approval of the settlement agreement [25].

2. One of the features of corporate disputes is that individuals who are participants in corporations not only on the territory of the Russian Federation, but also under the jurisdiction of foreign states can be parties to them. In particular, some difficulties may be caused by the choice of a mediator, namely, when the parties come to an opinion on the resolution of the dispute through a foreign specialist.

Russian legislation does not provide for a mechanism for foreign mediators to carry out their activities in the settlement of corporate disputes with the participation of Russian persons. In this case, the positive experience of foreign countries can be used (for example, the UK and the USA).

3. If the dispute affects or may affect the rights and legitimate interests of third parties not participating in the mediation procedure, it does not apply (Part 5 of Article 1 of Law No. 193-FZ), which is confirmed by judicial practice [26]. Failure to involve such persons entails the recognition of the mediation agreement as invalid, due to the lack of consent of a third party, which is required by law.

\section{Conclusion}

The success of the application of the mediation procedure in corporate disputes settlement depends on compliance with the key principles that are defined by Law No. 193-FZ. These principles create conditions of complete trust between the parties to the dispute, which ensures the most effective dispute resolution.

Having studied the current legislation and judicial practice on the use of mediation in corporate disputes, the authors identified a number of unresolved issues, in particular, related to the impossibility of structuring conditions in a settlement agreement that are not enforceable within the framework of enforcement proceedings; the difficulty of attracting third parties for participation in corporate mediation; the implementation of mediation activities by foreign specialists on the territory of the Russian Federation.

The proposals and recommendations for improving the current legislation presented herein will ensure the effectiveness of the mediation procedure in corporate disputes settlement.

\section{References}

1. O.A. Khilukha, I.O. Matviichuk, L.G. Lipych, Scientific Bulletin of Polissia, 3(15), 12-18 (2018). https://doi:org/10.25140/2410-9576-2018-3(15)-83-89

2. Ts. Shamlikashvili, Vestnik FIM, 3, 10-25 (2017)

3. E.V. Evdokimov, Actual problems of using alternative forms of conflict resolution in the modern world, in Proceedings of the All-Russian Scientific and Practical Conference - Mediation in the modern world: problems and development, SWSU, Kursk, 78-80 (2019)

4. T.A. Nigmatullina, Political Mediation, (Yurayt Publishing House, Moscow, 2018). Accessed on: June 12, 2020. [Online]. Available: https://urait.ru/bcode/438923 
5. I. Svensson, International Encyclopedia of the Social \& Behavioral Sciences, 627-631 (Elsevier BV, Amsterdam, 2015). https://doi:org/ 10.1016/B978-0-08-097086-8.96044-6

6. D.O. Altukhov, Development of mediation in Russia: problems and prospects, in Proceedings of the All-Russian Scientific and Practical Conference - Mediation in the modern world: problems and development, SWSU, Kursk, 16-19 (2019). Accessed on: June 12, 2020. [Online]. Available: https://swsu.ru/structura/up/flmk/kip/folder4/2019/

7. D.V. Baimakov, Mediation in modern society, in Proceedings of the All-Russian Scientific and Practical Conference - Mediation in the modern world: problems and development, SWSU, Kursk, 26-29 (2019). Accessed on: June 12, 2020. [Online]. Available: https://swsu.ru/structura/up/flmk/kip/folder4/2019/

8. N.O. Elokhina, Molodoi Ucheniy, 28(266), 116-119 (2019). Accessed on: June 12, 2020. [Online]. Available: https://moluch.ru/archive/266/61575/

9. V.P. Sorokin, Bulletin of the Arbitration Court of the Moscow District, 2, 54-65 (2020). Accessed on: June 12, 2020. [Online]. Available: https://duvernoixlegal.ru/files/stat_ya_natalii_afanas_evoj-szhatyj.pdf

10. Yu.A. Virchenko, Actual problems of our time: science and society, 4, 16-20 (2016). Accessed on: June 12, 2020. [Online]. Available: https://e-lanbook-com.ezproxy.ranepa.ru:2443/journal/issue/306297

11. A.N. Azarnova, Mediation: The Art of Reconciliation: The Technology of Mediation, in Conflict Resolution (InfotropicMedia, Moscow, 2015). Accessed on: June 12, 2020. [Online]. Available: https://e.lanbook.com/book/62437

12. S.I. Kalashnikov, Mediation in the field of civil jurisdiction, (InfotropicMedia, Moscow, 2011). Accessed on: June 12, 2020. [Online]. Available: https://e.lanbook.com/book/58064

13. A.A. Maksurov, M.V. Talanova Mediation in law: legal technology of mediation procedures (EcoOnis, Moscow, 2014). Accessed on: June 12, 2020. [Online]. Available: http://www.iprbookshop.ru.ezproxy.ranepa.ru:3561/35261.html

14. A.N. Ostrovsky, L.V. Sventitskene, Management, 5, 1-17 (2018). Accessed on: June 12, 2020. [Online]. Available: https://e-lanbook-com.ezproxy.ranepa.ru:2443/journal/issue/311436

15. N.G. Frolovskiy, Civil Law, 5, 22-24 (2020). https://doi:org/10.18572/2070-2140-2020-5-22-24

16. V.I. Malkina, Lawyer, 4, 46-54 (2018). Accessed on: June 12, 2020. [Online]. Available: http://www.lawinfo.ru/assets/files/Lawyer/2018/4/Lawyer_4_18-7.pdf. https://doi:org/10.18572/1812-3929-2018-4-46-54

17. D.V. Lipich, E.Iu. TSukanova, Corporate conflict as an integral element of corporate legal relations in the Russian Federation, in Proceedings of the Russian science: goals and objectives, 7-10 (2018). https://doi:org/10.18411/sr-10-06-2018-14

18. E.F. Baibekova, I.V. Kalimullina, Bulletin of the Saratov State Law Academy, 2(133), 245-252 (2020). Accessed on: June 12, 2020. [Online]. Available: http://www.сгюа.pф/documents/vestnik/02_2020.pdf. https://doi:org/10.24411/2227-7315-2020-10059

19. V.K. Andreev, V.A. Laptev, Corporate law in modern Russia (Publishing house Prospect, Moscow, 2017) 
20. On an alternative procedure for disputes settlement with the participation of a mediator (mediation procedure), Federal law of 27.07.2010. Accessed on: June 12, 2020. [Online]. Available: http://www.pravo.gov.ru

21. E.K. Kirgizova, Mediation as an alternative way to resolve a corporate conflict, in Proceedings of the International Scientific-Practical Conference "Business Cooperation as a Resource of Sustainable Economic Development and Investment Attraction", ISPCBC 2019, Accessed on: June 12, 2020. [Online]. Available::izdatelstvo.bgu.ru/epm/dl.ashx?id=1213

22. Arbitration Procedure Code of the Russian Federation dated 14.06.2002. Accessed on: June 12, 2020. [Online]. Available: http://www.pravo.gov.ru

23. Judicial statistics of the Judicial Department at the Supreme Court of the Russian Federation. Accessed on: June 12, 2020. [Online]. Available: http://www.cdep.ru/index.php?id=80

24. S.K. Zagainov, V.O. Abolonin (eds.), Commercial Mediation: Theory and Practice, (Publishing house Infotropic Media, Moscow, 2012)

25. Determination of the Arbitration Court of the Rostov Region dated April 29, 2019 in case No. A53-18815/19, Accessed on: June 12, 2020. [Online]. Available: https://rospravosudie.com/

26. Determination of the Arbitration Court of Chelyabinsk dated 16.10.2018 in case No. A76-25266/2018, Accessed on: June 12, 2020. [Online]. Available: https://rospravosudie.com/ 